\title{
Conceptual Model of Contractor Satisfaction in the Industrialized Building System (IBS) Implementation
}

\author{
Riduan Yunus ${ }^{1, a^{*},}$ Md Asrul Nasid Masrom²,b ${ }^{2}$ Abd Halid Abdullah ${ }^{1, c}$ \\ and Fajaruddin Mustakim ${ }^{1, d}$ \\ ${ }^{1}$ Faculty of Civil and Environmental Engineering, Universiti Tun Hussein Onn Malaysia, Batu Pahat, \\ Johor, Malaysia \\ ${ }^{2}$ Faculty of Technology Management and Business, Universiti Tun Hussein Onn Malaysia, Batu \\ Pahat, Johor, Malaysia \\ ariduan@uthm.edu.my, basruln@uthm.edu.my, 'abdhalid@uthm.edu.my, dfajardin@uthm.edu.my
}

Keywords: satisfaction, contractor, measurement, Industrialized Building System (IBS)

\begin{abstract}
Most construction projects have been recognized as underperformance due to the increase numbers of delays, cost overruns and poor quality construction. The inability of contractors to meet clients' expectation has been found as one of the main causes that contribute to the project failure. Alternatively, key players are encouraged to shift from the conventional method towards Industrialized Building System (IBS). Also known as prefabrication, previous researchers proved that IBS is able to minimize on-site works and increase the building quality in a controlled environment. However, the take up rate of IBS in Malaysian construction industry is still low as compared to developed countries basically due to incapability of contractors in mastering an advanced technology and their negative perceptions in IBS implementation. In addition, a limited subjective performance measurement, particularly to evaluate contractors' satisfaction level in implementing the IBS construction is still neglected. This is a review paper for an on-going research in examining contractor satisfaction levels on the IBS implementation and its attributes. The measurements are based on contractor perception instead of the typical approaches that solely concerned with objective measures (time, cost and quality). As a result, several attributes that integrate sustainability elements (economical, environmental, social, and institutional factors) are also determined. These attributes are then developed through systematic analysis to enhance the ability of IBS in improving contractors' satisfaction. The developed framework is expected to help the project team in performing IBS projects more efficiently, ensuring the quality meet the standards and encouraging effective communication between participants. Moreover, the findings will be useful to assist contractors in enhancing competitiveness, increase company reputation and improve project deliveries to meet global challenges.
\end{abstract}

\section{Introduction}

Construction industry is the main contributors to the development of the country. It is paramount to ensure the performance of this industry meeting the standards. There have been numerous efforts to improve outcomes of construction performance. Yang [1] claimed that the traditional desired goals of cost, time and quality are no longer sufficient to meet the current challenges. Construction projects and activities nowadays must be completed with sustainability goals as the fundamentals of project development. The success of construction projects are now measured through their ability of reducing resources, minimizing carbon emissions and conserving of biodiversity. The evaluation of the performance should include soft measurements that consider participants' satisfaction in order to improve the existing methods.

Several researchers [2-4] highlighted that the most crucial aspect in ensuring the success of any construction project is participants' satisfaction. If one or more participants do not satisfy with the ongoing project, most likely delays, cost overruns and poor quality will occur and consequently, will increase the number of disputes and conflicts. 
On the other hand, Industrialized Building Systems (IBS) or can be defined as integrated systems that employ a combination of ready-made components in the construction of buildings have a huge potential in improving sustainability. The characteristics of the system which increase productivity rate and minimize negative impacts to environments, such as optimizing utilization of resources and minimizing construction waste, undoubtedly improve sustainablity deliverables of the construction projects. As a developing country, the Malaysian government urges the construction players to shift from conventional practices to IBS-based construction.

Contractor as one of key players in the IBS implementation requires dealing with construction management and resolving issues in the project development [2]. Xiong et al. [3] emphasized that contractors are responsible for the actual production work involved, such as schedule management, cost management and quality management. Their role is critical to the success of projects. Therefore, to maintain the level of contractor satisfaction at acceptable level is significant in order to maintain the energy and level of teamwork of project.

However, several previous researches have been focusing more on the client and end user satisfaction but less attention on the contractor satisfaction [3, 4]. Masrom et al. [4] stated that dissatisfaction of contractor could hinder a performance-enhancing environment and degrade the quality of project outcomes.

In this context, there is a need to develop a better understanding of contractor satisfaction measurement to enhance the productivity for IBS implementation. A conceptual model developed in this study is to provide a systematic assessment and help the stakeholders to understand the significant factors which relate to contractor satisfaction. In light of findings, an ongoing study aimed at formulating conceptual models of contractor satisfaction that provide a systematic measurement for the IBS implementation, significant factors related to contractor satisfaction and operation of IBS building products are explored.

\section{Industrialized Building System}

According to Construction Industry Development Board (CIDB) [6], there are five characteristics of IBS, namely, prefabrication, offsite production, mass production (repeatability), standardized components and design using modular coordination. These characteristics are taken into account when the CIDB assesses the level of IBS percentages used for construction projects in Malaysia. The score of the assessment is a reflection of a total reduction of site labour, waste minimization, optimization of resources' usage, better quality, neater and safer construction sites, faster project completion and optimization of construction cost.

Yunus and Yang [7] stated that awareness on the importance of sustainability has set a higher expectation among the participants in delivering a construction project. It requires an integrated approach with a broader perspective in encouraging industry players to complete a project within limited resource consumption, minimal carbon emissions and preserve our environment. Previous researchers stated that IBS applications can improve the quality of production, reduce environmental effects and improve work productivity [8-9].

However, proper planning and strategies are required in dealing with this to prevent unnecessary additional cost, unpleasant community disturbance and decrement of environment performance. These problems will reduce the level of satisfaction of construction participants. Early engagements among the participants provide an opportunity for them to understand their responsibilities and have a clear picture on the project objectives.

Limited research on the contractor satisfaction has hindered the potential of IBS to be understood by the construction players. Moreover, negatives perception such as higher implementation cost, lack of flexibility and limited design innovations have led to slow adoption of this technology [1012]. Therefore, it is crucial to rectify the participants' understanding on the full potential of IBS in meeting the satisfaction of all stakeholders in IBS implementation. As asserted by Leung et al. [13], participants' satisfaction measurement may be useful in improving project performance as it assesses the reaction of key participants to any conflicts or problems. 


\section{Satisfaction Measurement}

Systematic measurement of performance is important to determine areas of improvement and measure the participants' perception of product or outcome. According to Xiong et al.[3], the motivation and cooperation among the participants can be improved by enhancing their satisfaction level. At the same time, any problems that occur in the construction activity can be easily resolved.

According to Masrom et al. [4], most of the satisfaction measurements used in the construction by addressing key contributory factors of the clients' satisfaction and neglecting the other stakeholders such as contractors and consultants. It is important to note that, the successful of the construction projects are not entirely depending on the clients' satisfaction. There is a compelling need for comprehensive satisfaction approach not only for client but also for all project stakeholders. This is important to achieve an improved construction project performance, especially to the contractors. The previous literature has shown that contractor satisfaction dimension is still undefined in this regards.

Verily, these limitations require a systematic measurement of the contractor satisfaction so that it could create a performance-enhancing environment. Having a proper framework would lead to harmonious working relationships between participants, the pursuit of continuous improvement and the integration of sustainability potentials in the IBS implementation, not only to accommodate our present needs but also for our future generations.

\section{Conceptual Model of IBS Contractor Satisfaction}

A conceptual model is defined as a theoretical construct from a scientific research that represents an external and explicit scenario in a reality world which faced by the participants [16]. Based on the satisfaction model developed by Ahmed and Kangari [15], satisfaction of the contractors in the IBS implementation can be adopted in the similar application. The modified model was developed from an extensive review of past researches as shown in Fig. 1. The level of satisfaction is depending on the subjective assessment. The assessment is according to contractor perceptions from the four sustainability dimensions, namely environmental, social, economical and institutional.

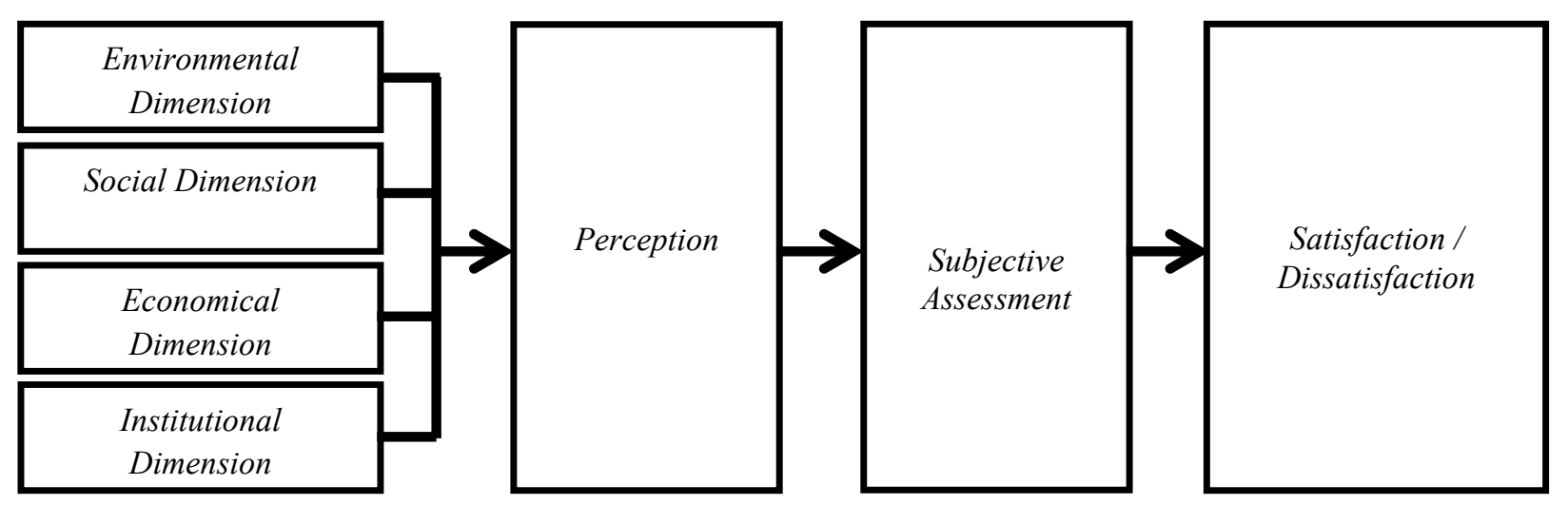

Fig. 1: Proposed Conceptual Model of IBS' Contractor Satisfaction

The factors in each dimension were determined from the previous researches [17-22]. Each factor had been validated by the industry experts before the main questionnaire was conducted. The quantitative approach is important to identify the significant of the factors in this research. The attributes of each factor were designed and weighted differently depending on the types of building construction over the entire of its lifecycle. The description of each dimensions and related factors are:

- Environmental Dimension: defined as any attributes that may increase the contractors' satisfaction in terms of their passion to preserve natural resources and reduce a negative impact to environment. Yunus and Yang [7] stated that IBS has many benefits in environmental, such 
as waste generation, waste disposal, material consumption, recyclable or renewable contents and site disruption. IBS and factory based work enable waste to be minimized from the early stage of construction. It can be optimized through computer aided design and manufacturing and fully or automated production lines. Having an effective design may ensure that resources are consumed efficiently, including construction materials and operational energy. These benefits are alleviated the burden of waste management and reduce the total production cost of building components to contractors.

- Social Dimension: defined as any attributes that offer long-term benefits and enhance the quality of life for local community and workers, which increase the contractors' satisfaction. The negative images (3D- dirty, dangerous and difficult) of conventional construction activities have caused local and new graduates to stay away from this industry [24]. The willingness of foreign workers to participate in this industry with low wages and poor conditions also encourages the industry to recruit them to meet the labour requirement. Therefore, IBS is seen as a potential solution to reduce dependency to foreign workers and attract local people to participate in this industry. Simultaneously, wealth distribution among the local communities can be stabilized, and their standard of living will be directly improved.

- Economical Dimension: defined as any attributes that reduce a tangible and intangible cost for the whole construction life cycle and improve economic profits. The economic considerations for contractors need to be expanded not only in traditional project management objectives (time, cost and quality), but it requires further evaluation for economic value such as speed of return investment, long term investment, higher potential to be re-selected in next projects and less site disruption $[8,25]$.

- Institutional Dimension: defined as any attributes that may increase the contractors' satisfaction in terms of their passion to ensure any planning to be carried out accordingly. Good governance able to enhance the long term shareholder value and protect the interest of other stakeholders [26]. With a full commitment which had been illustrated by the Malaysian government, the adoption of IBS construction could possibly increase constructability, minimize waste generation and reduce dependency to unskilled foreign workers. Therefore, attributes such as government incentives, levi exemption and local authority's requirement could increase the level of contractors' satisfaction towards IBS implementation.

\section{Summary}

Full understanding on the potential of Industrialized Building System (IBS) may increase the level of contractors' satisfaction. The increment of contractor satisfaction can be developed through a comprehensive measure in construction projects which is not only focusing on time, cost and quality, but also include subjective measures. An integrated framework needs to be developed to provide a systematic assessment of the level of satisfaction and common understanding of contractors' satisfaction. This paper reports an on-going research aimed at establishing an integrated model and guideline for IBS implementation. Sustainable elements have been identified as necessary elements that potentially increase contractors' satisfaction in projects. The next phase of research will determine the satisfaction factors through consensus among contractors on the IBS construction. The developed model is expected to help project team in performing IBS projects to be more efficiently in ensuring the quality meet the standards and encouraging effective communication between participants. The findings of the research could also be useful to assist contractors in enhancing their competitiveness, increase their reputation and improve the project implementation. 


\section{References}

[1] Yang, J., Editorial: Promoting integrated development for smart and sustainable built environment. Smart and Sustainable Built Environment, 2012. 1(1).

[2] Kamar, K.A.M., Z.A. Hamid., M.K. Ghani., A.H.A. Rahim., M.A.M. Zain. and F. Ambon., Business Strategy of Large Contractors in Adopting Industrialised Building System (IBS): The Malaysia Case. Journal of Engineering Science and Technology, 2012. 7(6): p. 774 - 784

[3] Xiong, B., M. Skitmore., B. Xia., M.A. Masrom., K. Ye. and A. Bridge., Examining the influence of participant performance factors on contractor satisfaction: A structural equation model. International Journal of Project Management, 2014. 32(3): p. 482-491.

[4] Masrom, M.D.A., M. Skitmore, and A. Bridge, Determinants of contractor satisfaction. Construction Management and Economics, 2013. 31(7): p. 761-779.

[5] Kärnä, S., V.M. Sorvala, and J.M. Junnonen, Classifying and clustering construction projects by customer satisfaction. Facilities, 2009. 27(9-10): p. 387-398.

[6] Construction Industry Development Board (CIDB), Manual for IBS Contect Scoring System (IBS SCORE). 2010, Perpustakaan Negara Malaysia: Kuala Lumpur, Malaysia.

[7] Yunus, R. and J. Yang, Improving ecological performance of industrialized building systems in Malaysia. Construction Management and Economics, 2014. 32(1-2): p. 183-195.

[8] Blismas, N., C. Pasquire, and A. Gibb, Benefit evaluation for off-site production in construction. Construction Management and Economics, 2006. 24(2): p. 121-130.

[9] Tam, C.M., V.W.Y. Tam., J.K.W. Chan. and W.C.Y. Ng., Use of prefabrication to minimize construction waste - a case study approach. International Journal of Construction Management \& Economics, 2005. 5(1): p. 91-101.

[10] Yunus, R. and J. Yang, Critical sustainability factors in industrialised building systems. Construction Innovation: Information, Process, Management, 2012. 12(4): p. 447 - 463.

[11]Abd Hamid, Z., K.A.M. Kamar., M.Z.M. Zain., M.K. Ghani. and A.H.A. Rahim., Industrialised Building System (IBS) in Malaysia: The Current State and R\&D Initiatives Malaysian Construction Research Journal (MCRJ), 2008. 1(2): p. 1-11.

[12] Gibb, A.G.F., Standardization and pre-assembly-distinguishing myth from reality using case study research. Construction Management and Economics, 2001. 19(3): p. 307 - 315.

[13]Leung, M.Y., S.T. Ng, and S.O. Cheung, Measuring construction project participant satisfaction. Construction Management and Economics, 2004. 22(3): p. 319-331.

[14]Chan, A.P.C. and D.W.M. Chan, Developing a benchmark model for project construction time performance in Hong Kong. Building and Environment, 2004. 39(3): p. 339-349.

[15]Ahmed, S.M. and R. Kangari, Analysis of client-satisfaction factors in construction industry. Journal of Management in Engineering, 1995. 11(2): p. 36-44.

[16] Cavana, R.Y., B.L. Delahaye, and U. Sekaran, Applied business research: qualitative and quantitative methods. 2001, New York: John Wiley and Sons, Inc.

[17]Blismas, N., C. Pasquire, and A. Gibb, Benefit evaluation for off-site production in construction. Construction Management and Economics, 2006. 24(2): p. 121 - 130.

[18]Chen, Y., G.E. Okudan, and D.R. Riley, Sustainable performance criteria for construction method selection in concrete buildings. Automation in Construction, 2010. 19(2): p. 235-244.

[19]Jaillon, L. and C.S. Poon, Sustainable construction aspects of using prefabrication in dense urban environment: a Hong Kong case study. Construction Management and Economics, 2008. 26(9): p. 953 - 966.

[20]Luo, Y., R. Riley., M.J. Horman. and G.O. Kremer., Decision Support Methodology for Prefabrication Decisions on Green Building Projects. in Symposium on Sustainability and Value Through Construction Procurement. 2008. University of Salford: University of Salford.

[21]Nelms, C.E., A.D. Russell, and B.J. Lence, Assessing the performance of sustainable technologies: a framework and its application. Building Research \& Information, 2007. 35(3): p. $237-251$. 
[22] Soetanto, R. and D.G. Proverbs, Modelling the satisfaction of contractors: the impact of client performance. Engineering, Construction and Architectural Management, 2002. 9(5/6): p. 453465.

[23]Jaillon, L., C.S. Poon, and Y.H. Chiang, Quantifying the waste reduction potential of using prefabrication in building construction in Hong Kong. Waste Management, 2009. 29(1): p. 309-320.

[24] Abdul Rahman, H., C. Wang., L.C. Wood. and S.F. Lowa., Negative impact induced by foreign workers: Evidence in Malaysian construction sector. Habitat International, 2012. 36: p. 433443.

[25] Jaillon, L. and C.S. Poon, Design issues of using prefabrication in Hong Kong building construction. Construction Management and Economics, 2010. 28(10): p. 1025 - 1042.

[26]Carrillo, E.F.P., Corporate Governance: Shareholders' interests' and other stakeholders' interest. Corporate Ownership \& Control, 2007. 4(4): p. 96-102. 